\title{
Awareness of Human Papillomavirus Vaccine Among Dental Students
}

\author{
Gaye Keser (D), Filiz Namdar Pekiner (10 \\ Marmara University, Faculty of Dentistry, Department of Oral Diagnosis and Radiology, Istanbul, Turkey. \\ Correspondence Author: Gaye Keser \\ E-mail:gaye.sezgin@marmara.edu.tr \\ Received: 07.05.2020 Accepted: 02.10.2020
}

\begin{abstract}
Objective: More recently, HPV infection has been portrayed as a vital risk factor for head and neck squamous cell carcinoma (HNSCC). Dentistry students need comprehensive information about HPV to provide accurate advice to their patients. The aim of this study is 4th and 5th grade students' awareness about HPV vaccination.
\end{abstract}

Methods: A questionnaire consisting of 7 questions was applied to 226 students (102 4th grade and 126 th grades), who were studying at Marmara University Faculty of Dentistry. In this survey, students' knowledge level and awareness were examined.

Results: In our study 75 (33.1\%) of the participants were male and 151 (66.8\%) were female. The rates of agreement of 4 th grade students (96.1\%) with the proposition "It is important that oral health professionals play an active role in the general medical condition of their patients." were statistically significantly lower than the 5 th grade students $(97.6 \%)$ ( $p: 0.010 ; p<0.05)$. A statistically significant difference between grades in terms of participation rates in the statement "I got my HPV vaccine / I am thinking of getting it". The rate of participation of 5th grade (38.7\%) students in this statement was significantly lower than 4 th grades $(45.1 \%)(p: 0.019 ; p<0.05)$ and significantly higher in women $(47.7 \%)$ than in men $(29.3 \%)(p=0.005 ; p<0.05)$.

Conclusion: Comprehensive training and motivation for improving dentistry students awareness against HPV vaccine will also improve knowledge and attitudes of the dental students on HPV induced oral cancer.

Keywords: Human papillomavirus, oral cancer, squamous cell carcinoma, vaccine

\section{INTRODUCTION}

Oral cavity cancers are the seventh most frequently existing cancer and, in terms of mortality, the ninth fatal by cancer region in the world as portrayed by World Cancer Report 2014 (1-7). Human papillomavirus (HPV) leads to approximately $72 \%$ of male and $63 \%$ of female oropharyngeal cancers (8). It has been reported that HPV is responsible for $91 \%$ of anal cancers, $75 \%$ of vaginal cancers and $60 \%$ of oropharyngeal cancers in the United States (9). While oral cancer rates are growing overall, HPV-related oral cancer is rising undoubtfully and requires a prevention attempts focused on HPV (10).

For the etiology of oropharyngeal cancer, various studies have portrayed HPV as a factor (10-15). It has been reported that, 24 types of HPV , 1, 2, 3, 4, 6, 7, 10, 11, 13, 16, 18, 30, $31,32,33,35,45,52,55,57,59,69,72$, and 73 , have been related with benign and 12 types, $2,3,6,11,13,16,18,31$, $33,35,52$, and 57 , with malignant lesions in the oral cavity $(16,17)$.

The recently introduced two HPV vaccines, bivalent and quadrivalent types, for HPV infection is active against subtypes of HPV which are related to genital warts, cervical cancer, and cancers including oropharyngeal cancer. Evidence shows the possibility that HPV vaccination may be effective in decreasing the incidence of oral cancer, however, the assessment of HPV vaccination for oral cancer prevention is still debatable (18). The results of a study that was conducted in Belgium in order to evaluate awareness of students about HPV infection showed that, 95\% of medical students were aware of HPV and $92 \%$ were aware of vaccinations and immunity against HPV, while only $46 \%$ knew that HPV could cause anogenital cancer (19). In a study by Lorenzo et al. (20), a survey was handed out to 240 dental students, of which 158 returned it. Most of the students described not been vaccinated against HPV ( $\mathrm{n}=81,51.3 \%$ ) and admitted that HPV infection was related to oropharyngeal cancer (75\%).

Dentists play a crucial role in examination of the oral cavity to determine potential malignant lesions. As a result of our literature review, it has been found that there is not enough information and awareness about HPV vaccination related oropharyngeal squamous cell carcinoma among dentistry students in Turkey. The aim of this study is to evaluate 
awareness of 4th and 5th grade students of Marmara University Faculty of Dentistry about HPV vaccination.

\section{METHODS}

This study was conducted at Marmara University Faculty of Dentistry, Istanbul, Turkey A self-administered survey was applied to 226 students (102 $4^{\text {th }}$ grade and $1245^{\text {th }}$ grade). Students' awareness were examined in a questionnaire consisting of 7 questions. The questions in the questionnaire were made without any names by specifying only the classes. All students from fourth and fifth year were invited to participate. Participation in the survey was anonymous, and voluntary.

\subsection{Statistical Analysis}

IBM SPSS Statistics 22.0 (IBM SPSS, Turkey) program is used for statistical analysis. Chi-square test and Fisher Freeman Halton test was used to compare descriptive statistics (mean, standard deviation, frequency) as well as qualitative data. Significance was assessed at $p<0.05$ level.

\subsection{Ethical Approval}

The study protocol of the study was approved by Marmara University School of Medicine Non-Interventional Clinical Research Ethics Committee with protocol number 09.2019.658.

\section{RESULTS}

The study was conducted on a total of 226 students, of which 75 (33.1\%) were male and 151 (66.8\%) were female. The mean age of the students was is $23.15 \pm 1.33$ years. 102 $(45.1 \%)$ of the students were $4^{\text {th }}$ grade, $124(54.9 \%)$ were $5^{\text {th }}$ grades.

According to gender, there was no statistically significant difference between the rates of participation in the statements "It is important that oral health professionals play an active role in the general medical condition of their patients", "HPV vaccine can promote earlier or more risky sexual behavior in adolescent patients", "I'm sure most patients will get it if I recommend getting an HPV vaccine", "It is the responsibility of oral health professionals to recommend HPV vaccine" and "I feel knowledgeable enough to discuss the HPV vaccine with patients and parents." ( $p>0.05$ ). There is no statistically significant difference between the rates of recommending HPV vaccine to male patients according to gender ( $p>0.05)$. The rates of participation in the statement "I got my HPV vaccine / I am thinking of getting it." is significantly higher in women $(47.7 \%)$ than in men $(29.3 \%)(p=0.005 ; p<0.05)$ (Table 1).

There was a statistically significant difference between the classes in terms of participation rates in the statement "It is important that oral health professionals play an active role in the general medical condition of their patients." The rate of participation of fourth grade $(96.1 \%)$ students in this proposition was significantly lower than $5^{\text {th }}$ grade $(97.6 \%)$ students $(p=0.010 ; p<0.05)$.

Table 1. Assessment of HPV vaccination according to gender

\begin{tabular}{|c|c|c|c|c|c|}
\hline & & Male & Female & Total & $p$ \\
\hline \multirow{3}{*}{$\begin{array}{l}\text { It is important } \\
\text { that oral health } \\
\text { professionals } \\
\text { play an active } \\
\text { role in the } \\
\text { general medical } \\
\text { condition of } \\
\text { their patients. }\end{array}$} & I agree & 72 (96\%) & $\begin{array}{c}147 \\
(97.4 \%)\end{array}$ & $\begin{array}{c}219 \\
(96.9 \%) \\
\end{array}$ & $0,822^{*}$ \\
\hline & $\begin{array}{c}\text { I do not } \\
\text { agree }\end{array}$ & $1(1.3 \%)$ & $2(1.3 \%)$ & $3(1.3 \%)$ & \\
\hline & No idea & $2(2.7 \%)$ & 2 (1.3\%) & $4(1.8 \%)$ & \\
\hline \multirow{3}{*}{$\begin{array}{l}\text { HPV vaccinecan } \\
\text { promote earlier } \\
\text { or more risky } \\
\text { sexual behavior } \\
\text { in adolescent } \\
\text { patients. }\end{array}$} & I agree & $5(6.7 \%)$ & $22(14.6 \%)$ & \begin{tabular}{|c|}
27 \\
$(11.9 \%)$ \\
\end{tabular} & $0,105^{* *}$ \\
\hline & $\begin{array}{c}\text { I do not } \\
\text { agree }\end{array}$ & $51(68 \%)$ & 83 (55\%) & \begin{tabular}{|c|}
134 \\
$(59.3 \%)$ \\
\end{tabular} & \\
\hline & No idea & \begin{tabular}{|c|}
19 \\
$(25.3 \%)$ \\
\end{tabular} & 46 (30.5\%) & \begin{tabular}{|c|}
65 \\
$(28.8 \%)$ \\
\end{tabular} & \\
\hline \multirow{3}{*}{$\begin{array}{l}\text { I'm sure most } \\
\text { patients will get } \\
\text { itifl recommend } \\
\text { getting theHPV } \\
\text { vaccine. }\end{array}$} & I agree & $21(28 \%)$ & $36(23.8 \%)$ & $\begin{array}{c}57 \\
(25.2 \%) \\
\end{array}$ & $0,659^{* *}$ \\
\hline & $\begin{array}{c}\text { I do not } \\
\text { agree }\end{array}$ & \begin{tabular}{|c|}
35 \\
$(46.7 \%)$ \\
\end{tabular} & $80(53 \%)$ & \begin{tabular}{|c|}
115 \\
$(50.9 \%)$ \\
\end{tabular} & \\
\hline & No idea & $\begin{array}{c}19 \\
(25.3 \%) \\
\end{array}$ & 35 (23.2\%) & $\begin{array}{c}54 \\
(23.9 \%) \\
\end{array}$ & \\
\hline \multirow{3}{*}{$\begin{array}{l}\text { It is the } \\
\text { responsibility of } \\
\text { oral healthcare } \\
\text { professionals to } \\
\text { recommend the } \\
\text { HPV vaccine. }\end{array}$} & I agree & \begin{tabular}{|c|}
47 \\
$(62.7 \%)$ \\
\end{tabular} & 71 (47\%) & \begin{tabular}{|c|}
118 \\
$(52.2 \%)$ \\
\end{tabular} & $0,085^{* *}$ \\
\hline & $\begin{array}{c}\text { I do not } \\
\text { agree }\end{array}$ & \begin{tabular}{|c|}
11 \\
$(14.7 \%)$ \\
\end{tabular} & $32(21.2 \%)$ & 43 (19\%) & \\
\hline & No idea & $\begin{array}{c}17 \\
(22.7 \%) \\
\end{array}$ & $48(31.8 \%)$ & $\begin{array}{c}65 \\
(28.8 \%) \\
\end{array}$ & \\
\hline \multirow{3}{*}{$\begin{array}{l}\text { I feel well } \\
\text { informed enough } \\
\text { to discuss the } \\
\text { HPV vaccine with } \\
\text { patients and } \\
\text { parents. }\end{array}$} & I agree & $\begin{array}{c}19 \\
(25.3 \%) \\
\end{array}$ & $29(19.2 \%)$ & $\begin{array}{c}48 \\
(21.2 \%) \\
\end{array}$ & $0,417^{* *}$ \\
\hline & $\begin{array}{c}\text { I do not } \\
\text { agree }\end{array}$ & \begin{tabular}{|c|}
44 \\
$(58.7 \%)$ \\
\end{tabular} & 89 (58.9\%) & $\begin{array}{c}133 \\
(58.8 \%) \\
\end{array}$ & \\
\hline & No idea & $12(16 \%)$ & $33(21.9 \%)$ & \begin{tabular}{|c|}
45 \\
$(19.9 \%)$ \\
\end{tabular} & \\
\hline \multirow{3}{*}{$\begin{array}{l}\text { I got my HPV } \\
\text { vaccine / I am } \\
\text { thinking of } \\
\text { getting it. }\end{array}$} & Yes & \begin{tabular}{|c|}
22 \\
$(29.3 \%)$ \\
\end{tabular} & 72 (47.7\%) & $\begin{array}{c}94 \\
(41.6 \%) \\
\end{array}$ & $0,005^{* *}$ \\
\hline & No & $\begin{array}{c}34 \\
(45.3 \%) \\
\end{array}$ & 38 (25.2\%) & $\begin{array}{c}72 \\
(31.9 \%) \\
\end{array}$ & \\
\hline & No idea & $\begin{array}{c}19 \\
(25.3 \%) \\
\end{array}$ & $41(27.2 \%)$ & $\begin{array}{c}60 \\
(26.5 \%) \\
\end{array}$ & \\
\hline \multirow{3}{*}{$\begin{array}{l}\text { Would you } \\
\text { recommend HPV } \\
\text { vaccine to male } \\
\text { patients? }\end{array}$} & Yes & $45(60 \%)$ & 82 (54.3\%) & $\begin{array}{c}127 \\
(56.2 \%) \\
\end{array}$ & $0,256 * *$ \\
\hline & No & $1(1.3 \%)$ & $9(6 \%)$ & $10(4.4 \%)$ & \\
\hline & No idea & $\begin{array}{c}29 \\
(38.7 \%)\end{array}$ & 60 (39.7\%) & $\begin{array}{c}89 \\
(39.4 \%)\end{array}$ & \\
\hline
\end{tabular}

${ }^{*}$ Fisher Freeman Halton Test; ${ }^{* *}$ Chi-square test.

There was no statistically significant difference between 4th and 5th grade students in terms of participation rates in the statement "HPV vaccine can promote earlier or more risky sexual behavior in adolescent patients", "I'm sure most patients will get it if I recommend getting the HPV vaccine", "It is the responsibility of oral healthcare professionals to 
recommend the HPV vaccine", "I feel well informed enough to discuss the HPV vaccine with patients and parents" and "Would you recommend HPV vaccine to male patients?" ( $p>$ 0.05).

Moreover a statistically significant difference between grades in terms of participation rates in the statement "I got my HPV vaccine / I am thinking of getting it". The rate of participation of $5^{\text {th }}$ grade $(38.7 \%)$ students in this statement was significantly lower than $4^{\text {th }}$ grades $(45.1 \%) \quad(p=0.019$; $\mathrm{p}<0.05$ ) (Table 2).

Table 2. Assessment of HPV-related cancer knowledge and HPV vaccination according to grade levels

\begin{tabular}{|c|c|c|c|c|c|}
\hline & & $4^{\text {th }}$ grade & $\begin{array}{c}5^{\text {th }} \\
\text { grade }\end{array}$ & Total & $p$ \\
\hline \multirow{3}{*}{$\begin{array}{l}\text { It is important } \\
\text { that oral health } \\
\text { professionals play } \\
\text { an active role in } \\
\text { thegeneral medical } \\
\text { condition of their } \\
\text { patients. }\end{array}$} & I agree & $\begin{array}{c}98 \\
(96.1 \%)\end{array}$ & $\begin{array}{c}121 \\
(97.6 \%)\end{array}$ & $\begin{array}{c}219 \\
(96.9 \%)\end{array}$ & $0.010 *$ \\
\hline & $\begin{array}{l}\text { I do not } \\
\text { agree }\end{array}$ & $0(0 \%)$ & $\begin{array}{c}3 \\
(2.4 \%)\end{array}$ & $3(1.3 \%)$ & \\
\hline & No idea & $4(3.9 \%)$ & $0(0 \%)$ & $4(1.8 \%)$ & \\
\hline \multirow{3}{*}{$\begin{array}{l}\text { HPV vaccine can } \\
\text { promote earlier } \\
\text { or more risky } \\
\text { sexual behavior } \\
\text { in adolescent } \\
\text { patients. }\end{array}$} & I agree & $\begin{array}{c}13 \\
(12.7 \%) \\
\end{array}$ & $\begin{array}{c}14 \\
(11.3 \%)\end{array}$ & $\begin{array}{c}27 \\
(11.9 \%)\end{array}$ & $0.945^{* *}$ \\
\hline & $\begin{array}{l}\text { I do not } \\
\text { agree }\end{array}$ & \begin{tabular}{|c|}
60 \\
$(58.8 \%)$ \\
\end{tabular} & \begin{tabular}{|c|}
74 \\
$(59.7 \%)$ \\
\end{tabular} & \begin{tabular}{|c|}
134 \\
$(59.3 \%)$
\end{tabular} & \\
\hline & No idea & $\begin{array}{c}29 \\
(28.4 \%)\end{array}$ & \begin{tabular}{|c|}
36 \\
$(29 \%)$
\end{tabular} & $\begin{array}{c}65 \\
(28.8 \%)\end{array}$ & \\
\hline \multirow{3}{*}{$\begin{array}{l}\text { I'm sure most } \\
\text { patients will get } \\
\text { it if I recommend } \\
\text { getting the HPV } \\
\text { vaccine. }\end{array}$} & I agree & \begin{tabular}{|c|}
26 \\
$(25.5 \%)$ \\
\end{tabular} & $\begin{array}{c}31 \\
(25 \%) \\
\end{array}$ & $\begin{array}{c}57 \\
(25.2 \%) \\
\end{array}$ & $0.467^{* *}$ \\
\hline & $\begin{array}{l}\text { I do not } \\
\text { agree }\end{array}$ & \begin{tabular}{|c|}
48 \\
$(47.1 \%)$ \\
\end{tabular} & $\begin{array}{c}67 \\
(54 \%) \\
\end{array}$ & \begin{tabular}{|c|}
115 \\
$(50.9 \%)$ \\
\end{tabular} & \\
\hline & No idea & \begin{tabular}{|c|}
28 \\
$(27.5 \%)$ \\
\end{tabular} & \begin{tabular}{|c|}
26 \\
$(21 \%)$ \\
\end{tabular} & \begin{tabular}{|c|}
54 \\
$(23.9 \%)$ \\
\end{tabular} & \\
\hline \multirow{3}{*}{$\begin{array}{l}\text { It is the } \\
\text { responsibility of } \\
\text { oral healthcare } \\
\text { professionals to } \\
\text { recommend the } \\
\text { HPV vaccine. }\end{array}$} & I agree & 49 (48\%) & $\begin{array}{c}69 \\
(55.6 \%) \\
\end{array}$ & $\begin{array}{c}118 \\
(52.2 \%) \\
\end{array}$ & $0.370^{* *}$ \\
\hline & $\begin{array}{l}\text { I do not } \\
\text { agree }\end{array}$ & $\begin{array}{c}19 \\
(18.6 \%) \\
\end{array}$ & \begin{tabular}{|c|}
24 \\
$(19.4 \%)$ \\
\end{tabular} & $43(19 \%)$ & \\
\hline & No idea & \begin{tabular}{|c|}
34 \\
$(33.3 \%)$ \\
\end{tabular} & $\begin{array}{c}31 \\
(25 \%) \\
\end{array}$ & \begin{tabular}{|c|}
65 \\
$(28.8 \%)$ \\
\end{tabular} & \\
\hline \multirow{3}{*}{$\begin{array}{l}\text { I feel well informed } \\
\text { enough to discuss } \\
\text { the HPV vaccine } \\
\text { with patients and } \\
\text { parents. }\end{array}$} & I agree & $\begin{array}{c}24 \\
(23.5 \%) \\
\end{array}$ & $\begin{array}{c}24 \\
(19.4 \%) \\
\end{array}$ & \begin{tabular}{|c|c}
48 \\
$(21.2 \%)$ \\
\end{tabular} & $0.744^{* *}$ \\
\hline & $\begin{array}{l}\text { I do not } \\
\text { agree }\end{array}$ & \begin{tabular}{|c|}
58 \\
$(56.9 \%)$ \\
\end{tabular} & $\begin{array}{c}75 \\
(60.5 \%) \\
\end{array}$ & \begin{tabular}{|c|c}
133 \\
$(58.8 \%)$ \\
\end{tabular} & \\
\hline & No idea & \begin{tabular}{|c|}
20 \\
$(19.6 \%)$ \\
\end{tabular} & \begin{tabular}{|c|}
25 \\
$(20.2 \%)$ \\
\end{tabular} & \begin{tabular}{|c|c}
45 \\
$(19.9 \%)$ \\
\end{tabular} & \\
\hline \multirow{3}{*}{$\begin{array}{l}\text { I got my HPV } \\
\text { vaccine / I am } \\
\text { thinking of getting } \\
\text { it. }\end{array}$} & Yes & $\begin{array}{c}46 \\
(45.1 \%) \\
\end{array}$ & $\begin{array}{c}48 \\
(38.7 \%)\end{array}$ & $\begin{array}{c}94 \\
(41.6 \%)\end{array}$ & $0.019 * *$ \\
\hline & No & $\begin{array}{c}23 \\
(22.5 \%) \\
\end{array}$ & $\begin{array}{c}49 \\
(39.5 \%) \\
\end{array}$ & $\begin{array}{c}72 \\
(31.9 \%) \\
\end{array}$ & \\
\hline & No idea & \begin{tabular}{|c|}
33 \\
$(32.4 \%)$ \\
\end{tabular} & $\begin{array}{c}27 \\
(21.8 \%)\end{array}$ & $\begin{array}{c}60 \\
(26.5 \%) \\
\end{array}$ & \\
\hline \multirow{3}{*}{$\begin{array}{l}\text { Would you } \\
\text { recommend HPV } \\
\text { vaccine to male } \\
\text { patients? }\end{array}$} & Yes & \begin{tabular}{|c|}
54 \\
$(52.9 \%)$ \\
\end{tabular} & \begin{tabular}{|c|}
73 \\
$(58.9 \%)$ \\
\end{tabular} & \begin{tabular}{|c|}
127 \\
$(56.2 \%)$ \\
\end{tabular} & $0.498^{* *}$ \\
\hline & No & $6(5.9 \%)$ & $\begin{array}{c}4 \\
(3.2 \%)\end{array}$ & $\begin{array}{c}10 \\
(4.4 \%)\end{array}$ & \\
\hline & No id & $\begin{array}{c}42 \\
(41.2 \%)\end{array}$ & $\begin{array}{c}47 \\
(37.9 \%)\end{array}$ & $\begin{array}{c}89 \\
(39.4 \%)\end{array}$ & \\
\hline
\end{tabular}

${ }^{*}$ Fisher Freeman Halton Test; ${ }^{* *}$ Chi-square test.

\section{DISCUSSION}

Oral cancer is commonly classified as head and neck cancer, and globally, head and neck squamous cell carcinoma (HNSCC) is the sixth to ninth most common malignancy $(18,21)$. The main risk factors for head and neck cancers are increasing age, smoking and alcohol consumption (2224). Recently, HPV infection has been portrayed as a vital risk factor for HNSCC and the majority (82\%) of HPV-positive HNSCCS are due to HPV-16 infection (25).

The current HPV vaccination approach for cervical cancer prevents development of some oral squamous cell cancer, as broadly defined, counting some anogenital carcinoma, such as anal, penile, and vulvar cancers. The Gardasil vaccine for strains 6,11,18,16 of HPV and Cervarix for strains 16 and 18 was introduced and are recommended for prevention of HPV infection in 11-12 years old individuals (26). The prophylactic HPV vaccines may reduce oropharyngeal cancer incidence by protecting against HPV-16 and HPV-18 infection (27).

Dentists should be involved in improvement of knowledge and healthy attitudes of vaccination to prevent HPV infections and oral cancer associated with HPV $(18,28)$. Lorenzo-Pouso et al. (20) assessed 158 dental students for their knowledge of HPV and the study composed of 89 preclinical students (56.3\%) and 69 clinical students (43.7\%). They found that $48.7 \%$ of students declared to be vaccinated against HPV and that $57.7 \%$ of female students and $27.7 \%$ of male students reported to be vaccinated. Hashemıpour et al. (9) conducted questionnaire on 290 medical and dental students to evaluate awareness of medical and dental students about the infection and vaccination of the human papilloma virus. In their study, 39.9\% of respondents were not familiar with the HPV vaccine and $62.1 \%$ tended to be vaccinated. Rajiah et al. (29) assessed the influence of final year dental students' knowledge and attitude for human papillomavirus infection of cervical cancer on willingness to pay for vaccination. They reported that dental students' knowledge on HPV and cancer has no affect on their attitude towards HPV vaccines yet about $90 \%$ of students would be vaccinated if sufficient information was available. The results also revealed that female students have more knowledge than their males.

In our study the rates of participation in the statement "I got my HPV vaccine / I am thinking of getting it." is significantly higher in women $(47.7 \%)$ than in men in our study $(29.3 \%)$ $(p=0.005 ; p<0.05)$.

Poelman et al. (30) evaluated knowledge of HPV and oral cancer among dentistry students and they showed in their study that one third of the female students were vaccinated against HPV. It is also reported that Dutch dental students thought dentists should discuss this subject with their patients, which suggests students are ready to discuss the HPV vaccine with their patients. However, in our study there was a statistically significant difference between the classes in terms of participation rates in the statement "It is important that oral health professionals play an active role in the general medical condition of their patients". The 
rate of participation of fourth grade $(96.1 \%)$ students in this proposition was significantly lower than $5^{\text {th }}$ grade $(97.6 \%)$ students $(p=0.010 ; p<0.05)$.

\section{CONCLUSION}

In conclusion, early detection of oral cancer dentists play a vital role which would conclude in a favorable outcome for the patients. Future dentists are willing to take part in prevention of HPV-related oral cancer. Therefore, screening for oral cancer and education about HPV vaccination should be essential elements of the dental curriculum.

\section{Acknowledgements}

This study was presented as on oral presentation in International Congress of Oral Cancer that was held on March 4-6 ${ }^{\text {th }}$ in Eskişehir , Turkey.

This study is a continuation of research published with manuscript number JCED-D-19-00412 conducted by Dr. Gaye Keser.

\section{REFERENCES}

[1] Keser G, Pekiner FN. Assessing oral cancer awareness among dental students. J Cancer Educ 2019;34(3):512-518.

[2] Keser G, Yllmaz G, Pekiner FN. Assessment of knowledge level and awareness about human papillomavirus among dental students. J Canc Educ 2020.

[3] Oliveira JMB, Pinto LO, Lima NGM, Almeida GCM. Oral cancer: assessment of academic dentistry and nursing knowledge as for the risk factors and diagnostic procedures. Rev Bras Canc 2013;59: 211-218.

[4] Carter LM, Ogden GR. Oral cancer awareness of undergraduate medical and dental students. BMC Med Educ 2007; 15:44-52.

[5] Kebabcıoğlu Ö, Pekiner FN. Assessing oral cancer awareness among dentists. J Cancer Educ 2018;33(5):1020-1026.

[6] Özbayrak S, Pekiner FN. Oral cancers: clinical findings and treatment approaches in point of early diagnosis. Quintessence Publication, 2016, İstanbul.

[7] Stewart BW, Wild CP. World cancer report. International Agency for Research on Cancer, Lyon, 2014.

[8] Viens LJ, Henley SJ, Watson M, Markowitz LE, Thomas CC, Thompson TD, Razzaghi H, Saraiya M. Human papillomavirusassociated cancers - United States, 2008-2012. MMWR Morb Mortal Wkly Rep 2016; 65:661-666.

[9] Hashemıpour MA, Parızı, Molouk T, Modares, Yasaman AZ, Sepehr P. Knowledge of medical and dental Iranian students about the infection and vaccination of human papilloma virus. Pesqui Bras Odontopediatria Clín Integr. 2019; 19:e4459.

[10] Chaturvedi AK, Engels EA, Pfeiffer RM, Hernandez BY, Xiao W, Kim E, Jiang B, Goodman MT, Sibug-Saber M, Cozen W, Liu L, Lynch CF, Wentzensen N, Jordan RC, Altekruse S, Anderson WF, Rosenberg PS, Gillison ML. Human papillomavirus and rising or opharyngeal cancer incidence in the United States. J Clin Oncol 2011; 29:4294-4430.

[11] Cleveland JL, Junger ML, Saraiya M, Markowitz LE, Dunne EF, Epstein JB. The connection between human papillomavirus and oropharyngeal squamous cell carcinomas in the United States: implications for dentistry. J Am Dent Assoc 2011;142:915-924.
[12] Gillison ML, Chaturvedi AK, Anderson WF, Fakhry C. Epidemiology of human papillomavirus-positive head and neck squamous cell carcinoma. J Clin Oncol 2015; 33(29):32353242.

[13] Deschler DG, Richmon JD, Khariwala SS, Ferris RLWM. The new head and neck cancer patient-young, nonsmoker, nondrinker, and HPV positive: evaluation. Otolaryngol Head Neck Surg2014; 351:375-338.

[14] Mehanna H, Beech T, Nicholson T, El-Hariry I, McConkey C, Paleri V, Roberts S. Prevalence of human papillomavirus in oropharyngeal and nonoropharyngeal head and neck cancersystematic review and meta-analysis of trends by time and region. Head Neck 2013; 35:747-755.

[15] Kreimer AR, Clifford GM, Boyle P, Franceschi S. Human papilloma virus types in head and neck squamous cell carcinomas worldwide: a systematic review. Cancer Epidemiol Biomark Prev 2005; 14:467-475.

[16] McQuillan G, Kruszon-Moran D, Markowitz LE, Unger ER, Paulose-Ram R. Prevalence of HPV in adults aged 18-69: United States, 2011-2014. NCHS Data Brief 2007; 280:1-8.

[17] Kojima A, Maeda H, Sugita Y, Tanaka S, Kameyama Y. Human papillomavirus type 38 infection in oral squamous cell carcinomas. Oral Oncol 2002; 38:591-596.

[18] Kim SM. Human papilloma virus in oral cancer. J Korean Assoc Oral Maxillofac Surg 2016; 42(6):327-336.

[19] Deriemaeker H, Michielsen D, Reichman G, Devroey D, Cammu $\mathrm{H}$. Knowledge about human papillomavirus and the human papillomavirus vaccine in Belgian students. Cent European J Urol 2014; 67(4):410-417.

[20] Lorenzo-Pouso Al, Gándara-Vila P, Banga C, Gallas M, Pérez-Sayáns M, García A, Daley EM, Gasamáns I. Human papillomavirusrelated oral cancer: Knowledge and awareness among Spanish dental students. J Cancer Educ 2019;34(4):782-788.

[21] Sun JR, Kim SM, Seo MH, Kim MJ, Lee JH, Myoung H. Oral cancer incidence based on annual cancer statistics in Korea. J Korean Assoc Oral Maxillofac Surg 2012; 38:20-28.

[22] Agalliu I, Gapstur S, Chen Z, Wang T, Anderson RL, Teras L, Kreimer AR, Hayes RB, Freedman ND, Burk RD. Associations of oral $\alpha-, \beta$-, and $\gamma$-human papillomavirus types with risk of incident head and neck cancer. JAMA Oncol 2016; 2:599-560.

[23] Joseph AW, D'Souza G. Epidemiology of human papillomavirusrelated head and neck cancer. Otolaryngol Clin North Am 2012; 45:739-764.

[24] Pelucchi C, Gallus S, Garavello W, Bosetti C, La Vecchia C. Alcohol and tobacco use, cancer risk for upper aerodigestive tract and liver. Eur J Cancer Prev 2008; 17:340-344.

[25] Ndiaye $C$, Mena $M$, Alemany L, Arbyn M, Castellsagué $X$, Laporte L, Bosch FX, de Sanjosé S, Trottier H. HPV DNA, E6/ E7 mRNA, and p16INK4a detection in head and neck cancers: a systematic review and meta-analysis. Lancet Oncol 2014; 15:1319-1331.

[26] Aljunid S, Zafar A, Saperi S, Amrizal M. Burden of disease associated with cervical cancer in Malaysia and potential costs and consequences of HPV vaccination. Asian Pac J Cancer Prev 2010; 11:1551-1559.

[27] Muñoz N, Bosch FX, Sanjosé SD, et al . Epidemiologic classification of Human Papillomavirus types associated with cervical cancer. N Engl J Med 2003; 348, 518-527.

[28] Arya SC, Agarwal N. Extended coverage of HPV vaccination in middle-aged adults to prevent oropharyngeal cancers. Hum Vaccin Immunother 2012; 8:95. 
[29] Rajiah K, Maharajan MK, Fang Num KS, How Koh RC. Knowledge about human papillomavirus and cervical cancer: predictors of HPV vaccination among dental students. Asian Pac J Cancer Prev 2017; 18:1573-1579.
[30] Poelman MR, BrandHS, Forouzanfar T, Daley EM, Jan Jager DH. Prevention of HPV-related oral cancer by dentists: assessing the opinion of Dutch dental students. J Cancer Educ 2018; 33: 1347-1354. 